\title{
Case Comment on R. v. MaRShall
}

\author{
W.H. HURLBURT*
}

\section{INTRODUCTION}

This comment is about the judgment of the majority of the Supreme Court of Canada in $R$. v. Marshall dated 17 September 1999, as varied by a memorandum of the Court dated 30 September 1999.' The comment focuses on the majority's decision that certain specific treaties contain a specific term. ${ }^{2}$ The specific treaties are the treaties entered into in 1760 and 1761 between the Governor of Nova Scotia, on the one hand, and the chiefs of various Mi'kmaq villages, on the other. ${ }^{3}$ The specific term is one that conferred on the various tribes "a treaty right to continue to obtain necessaries through hunting and fishing by trading the products of those traditional activities subject to restrictions that can be justified under the Badger test."

The comment deals only with the legal analysis and reasoning of the majority judgment. It has nothing to say about the appropriate way of dealing with the legal relationships between the general community and aboriginal peoples, nor does it have anything to say about what the fishing-right extends to or the extent to which it can be regulated.

LL.D. (Hon.), Q.C., of the Alberta Bar.

(1999), 177 D.L.R. (4th) 513 [hereinafter Marshall]. It is not necessary, for the purposes of this note, to refer to the Supreme Court of Canada's decision on the application for a rehearing, reported at (1999), 179 D.L.R. (4th) 193.

2 Binnie J. wrote the majority decision on behalf of himself, Lamer C.J.C., L'Heureux-Dube, Cory and Iacobucci JJ. McLachlin J. (as she then was) wrote the dissent, with Gonthier J. concurring. Marshall, supra note 1 at 519 , para. 3 of the judgment says that the trial judge "accepted as applicable the terms of a Treaty of Peace and Friendship signed on March 10, 1760." This does not actually say that the March 10,1760 treaty applies to Mr. Marshall, merely that its terms apply. A reference in para. 4 to "the treaty" seems to make the treaty itself applicable and so do references in paras. 5 and 7 , though they stop short of saying so. There is an occasional reference in the majority judgment to "the 1760-1761 treaties" as if it is the group of treaties which applies, which was the way the trial judge put it, and is consistent with the positions taken at trial by both the Crown and Mr. Marshall. Presumably, if one finds a treaty dated in 1760 or 1761 between the Crown and a Mi'kmaq group, one can conclusively assume that it contains the fishing-right term which the majority found to be contained in the March 10,1760 treaty, as the "1760-1761 treaties" are said to be identical. However, no list of the treaties which contain the term is given in the judgment.

$4 \quad$ lbid. at 546 , para. 56 . This note will usually refer only to the fishing right, which is what was in issue in the case. While the hunting right is closely associated, different regulatory and factual considerations apply to it, and the Supreme Court judgment deals specifically with the fishing right. 


\section{WAS A Fishing-RIGhtS TeRM INCLUDED IN THE MI'KMAQ Treaties?}

\section{A. Essential Points}

The following are the essential points which arise from the majority judgment:

1. No treaty term conferring a right to fish appears in the formal documents. The Mi'kmaq did not request nor bargain for the term. The Governor did not offer the term. The term was not discussed. Neither side raised the subject of such a term. ${ }^{s}$

2. The term would not be implied if the treaty were an ordinary commercial contract. $^{6}$

3. The ratio decidendi of the majority decision on the existence of the term is that the "honour of the Crown" requires that the term be implied."

These points will now be examined and amplified.

\section{B. Did the Parties Intend to Include a Fishing Right in the Treaty?}

\section{THE Formal DOCUMENT OF 10 MarCH 1760}

Under the formal document of 10 March 1760 , which the majority judgment takes to be the standard for the 1760-1761 Mi'kmaq treaties, the Mi'kmaq acknowledged and submitted to the jurisdiction of the Crown over Nova Scotia and Acadia and entered into a number of covenants incidental to that submission. The formal treaty document includes the following provision, which is the only reference to trading:

And I do further promise for myself and my tribe that we will not either directly nor indirectly assist any of the enemies of His most sacred Majesty King George the Second, his heirs or Successors, nor hold any manner of Commerce traffick nor intercourse with them, but on the contrary will as much as may be in our power discover and make known to His Majesty's Governor, any ill designs which may be formed or contrived against His Majesty's subjects. And I do further engage that we will not traffick, barter or Exchange any Commodities in any manner but with such persons or the managers of such Truck houses as shall be appointed or Established by His Majesty's Governor at Lunenbourg or Elsewhere in Nova Scotia or Accadia. ${ }^{8}$

On the face of it, this provision is, and is only, a covenant by the Mi'kmaq not to trade with the King's enemies and a further covenant not to trade their "Commodities"

Ibid. at 539, para. 42 . The judgment does not put it the way the text does, but analysis will show that the statement flows from the judgment.

Ibid. at 540-41, para. 44 .

lbid. at 540, para. 43.

Ibid. at 521-22, para. 5 [emphasis in original]. The majority decision does not make reference to the alternative of trade with persons appointed by the Governor. That alternative will therefore not be referred to in this comment. 
with anyone but "such persons or the managers of such Truck houses as shall be appointed or Established" by the Governor.

\section{ADMISSIBILITY OF EXTRINSIC EVIDENCE}

The majority judgment held that extrinsic evidence could be adduced to show that the truckhouse provision, literally interpreted, did not represent the intention of the treaty.

The majority gave three reasons for admitting extrinsic evidence:

1. Even in a modern commercial context, where rules of interpretation are more strict than those applicable to treaties, extrinsic evidence is admissible to show that a written document does not include all of the terms of an agreement.

2. Supreme Court of Canada decisions have held that extrinsic evidence of the historical and cultural context of a treaty may be received, even in the absence of ambiguity. ${ }^{10}$

3. It would be unconscionable for the Crown, when writing up a treaty, to ignore agreed upon terms."

These reasons are well-founded, though the first would be enough by itself.

\section{EVIDENCE OF THE INTENTION OF THE GOVERNOR AND THE MI'KMAQ WITH RESPECT TO TRUCKHOUSES}

The majority judgment canvasses at length historical events which led up to the signing of the treaty of 10 March $1760 .^{12}$ It makes a strong case for holding that in their treaty negotiations the Passamaquody and Maliseet were promised "truckhouses"13 at which the those tribes could trade their "peltry" for necessaries on favourable terms. Binnie J. quotes from the minutes taken by the Governor's secretary of a meeting between the Maliseet and Passamaquody and the Governor some days

Ibid. at 524, para. 10.

$10 \quad$ Ibid. at para. 11.

$11 \quad$ Ibid. at 524-25, para. 12.

$12 \quad$ Ibid. at 530-35, paras. 22-33.

13 The formal treaty document does not say anything about the time during which the obligation to provide truckhouses was to continue, nor did the Govemor's promise to the Maliseet/Passamaquoddy. The minority judgment held, in effect, that the Crown effectively terminated both the truckhouse obligation and the trade restriction, which was correlative, by unilaterally discontinuing the truckhouses. The majority held that it is pointless today to refer back to the covenant, but said that the disallowance of the enabling Nova Scotia legislation by the King had made the truckhouses "temporary" (ibid. at 545, para. 54), which, again, seems to suggest that the unilateral action of the Crown terminated its obligation. But, under the majority judgment, the trading-right and the fishing-right found by the majority, survive into perpetuity despite the disappearance of the obligation to provide a market and the consequent disappearance of the obligation to trade only at that market. 
before the conclusion of the March 10, 1760 Mi'kmaq treaty. ${ }^{14}$ The minutes show that the Maliseet and the Passamaquody, in response to the Governor's question whether there was anything further to be treated upon, answered, in effect, that they were directed to propose that "there might be a Truckhouse established for the furnishing them with necessaries, in Exchange for their Peltry"'s at Fort Frederick. The Governor replied that if a treaty was executed and ratified, a truckhouse would be established at Fort Frederick, and others would be established if necessary "for furnishing them with such Commodities as shall be necessary for them, in Exchange for their Peltry."16

Then, at a meeting between the Governor-in-Council and the Mi'kmaq chiefs on 29 February 1760, the terms of treaties with the Passamaquody and St. John's River Indians were communicated to the Mi'kmaq signatory to the March 10,1760 treaty, and the latter said that "all the Tribe of the Mickmaks would be glad to make peace on the same Conditions." 17 The Governor later reported that he had treated with the Mi'kmaq Indians "on the same terms" as the Maliseet and Passamaquody. ${ }^{18}$ So there is at least some foundation for importing into the Mi'kmaq treaties everything that was in the Passamaquody and Maliseet treaty or treaties. ${ }^{19}$

While the formal document of 10 March 1760 , looks very much like the intended embodiment of the whole of that treaty, there is at least some foundation to justify the majority judgment in holding that the British and the Mi'kmaq had agreed, and intended it to be part of their principal agreement, that the British would provide truckhouses at which the Mi'kmaq would be entitled to trade their peltry on favourable terms. Under ordinary principles of equity, a contract document which fails to give effect to the terms agreed upon by the parties can be rectified, and under these circumstances, it would indeed be unconscionable to hold the Mi'kmaq to the strict terms of the formal document, which included only their obligation and not the agreed correlative right to a market for their peltry on favourable terms. Even without proof of intention, the law would imply a term that the Mi'kmaq could not be required to trade at truckhouses unless truckhouses were provided, as the covenant of the Mi'kmaq to trade only at truckhouses would not have business efficacy if there were no truckhouses.

\section{SCOPE Of the TRUCKHOUSE Provision: "Peltry" or "COMmodities"?}

One point puzzles me. What the Maliseet/Passamaquoddy asked for, according to the majority judgment, was "a Truckhouse established for the furnishing them with necessaries, in Exchange for their Peltry." ${ }^{20}$ What the Governor promised was a truckhouse or truckhouses "for furnishing them with such Commodities as shall be

$14 \quad$ Ibid. at 533-34, para. 29.

is Ibid. [emphasis in original].

to Ibid.

17 Ibid. at 533, para. 28 [emphasis in original].

Ix Ibid.

19 The Maliseet and Passamaquoddy treaties are not quoted or described in the judgment. Presumably, they either formally contained a British promise in the terms of the Governor's promise or must be interpreted as containing such a promise. 
necessary for them, in Exchange for their Peltry."21 This was the promise which was, according to the majority judgment, "[t]he genesis of the Mi'kmaq trade clause"22 and which was therefore the foundation of the truckhouse obligation and thus of the trading and fishing rights which the majority found in the Mi'kmaq treaties. The logic of the majority position therefore requires a finding that the British obligation under the 1760 $1761 \mathrm{Mi}$ 'kmaq treaties was to provide "such Commodities as shall be necessary" for the Mi'kmaq in exchange for the "peltry" of the Mi'kmaq. It is safe to say dogmatically that "peltry," as a matter of language, does not include fish for consumption and did not include it in 1760; the majority judgment does not cite any evidence that would suggest that the Governor, the Maliseet, and the Passamaquoddy, or the Mi'kmaq thought that "peltry" included fish for consumption.

Now, it is true that the formal treaty document of 10 March 1760 said that the Mi'kmaq would not

traffick, barter or Exchange any Commodities in any manner but with such persons or the managers of such Truck houses as shall be appointed or Established by His Majesty's Governor at Lunenbourg or Elsewhere in Nova Scotia or Accadia."

The use of the word "Commodities" suggests that the trade restriction included everything that could be called a "commodity," which would include fish for consumption. But the whole foundation of the majority judgment is that it was the Governor's promise to the Maliseet/Passamaquoddy which was incorporated, for better or for worse, into the Mi'kmaq 1760-1761 treaties. This imposed an obligation on the Crown to provide truckhouses; a necessary consequence of that obligation included a conferral of a "trading right" on the Mi'kmaq. As a further necessary consequence of that obligation, combined with the operation of the "honour of the Crown," was a conferral on the Mi'kmaq of a treaty right to obtain the things which they were entitled and obliged to trade at the truckhouses. But the promise, and the request in response to which the promise was given, related to an exchange of "peltry" on the Mi'kmaq's side, for "commodities" on the British side, and it was that promise that was incorporated into the treaties.

As this is a point of interpretation and does not appear to have been taken by those involved, I will not pursue it further. ${ }^{24}$

See ibid., where the interchange of request and promise is quoted from the minutes of the meeting between the Governor and the Malisect/Passamaquoddy.

lbid.

Ibid. at 522, para. 5 [emphasis in original].

There was expert evidence that fish would be among the items that the Mi'kmaq would trade at truckhouses (ibid. at 536-38, paras. 37-38), but the majority decision does not cite any evidence that when the Maliseet/Passamaquoddy said "peltry," they meant to include fish. Even if regard can be had to the expert evidence to extend the meaning of what was said, there are unanswered questions. Does the fact that the Mi'kmaq traded some fish to truckhouses mean that the truckhouses must take all the fish that the Mi'kmaq chose to trade and that the Mi'kmaq could not trade any fish elsewhere? Did the truckhouses have facilities that enabled them to resell all the fish the Mi'kmaq could produce before it became unsaleable, or, alternatively, facilities that enabled them to preserve that quantity of fish for later sale or export? Did the Mi'kmaq intend to give up 


\section{EVIDENCE OF THE INTENTION OF THE GOVERNOR AND THE MI'KMAQ WITH RESPECT TO FISHING RIGHTS}

There are occasional suggestions in the majority judgment that some form of common intention can be found which includes a treaty term conferring fishing rights on the Mi'kmaq. For example:

The trade clause would not have advanced British objectives (peaceful relations with a self-sufficient Mi'kmaq people) or Mi'kmaq objectives (access to European "necessaries" on which they had come to rely) unless the Mi'kmaq were assured at the same time of continuing access, implicitly or explicitly, to a harvest of wildlife to trade..$^{25}$

No doubt the British wanted peaceful relations with a self-sufficient Mi'kmaq people and no doubt the Mi'kmaqs wanted access to necessaries. But what the parties' underlying objectives were is not the question. It would simply be wrong to say that an agreement includes the unexpressed underlying objectives and wants of the parties. The common intention that is to be sought in interpreting an agreement is a common intention to agree. The test of what is included in an agreement is what the parties agreed to or gave the objective appearance of agreeing to.

It is, in my submission, clear from the majority judgment, that neither the Maliseet/Passamaquoddy nor the Mi'kmaq asked for a fishing-right term, that the Governor did not offer a fishing-right term, and that neither party ever discussed a fishing-right term. The mere fact that the majority judgment does not suggest that a fishing-right term was ever discussed would be sufficient grounds for drawing an inference to that effect, given that the discussion of such a term, if it had occurred, would have been an important bulwark for the majority's decision and would necessarily have been mentioned. But the majority judgment makes a positive statement. After canvassing all the evidence, Binnie J. says:

The right to fish is not mentioned in the March 10,1760 document, nor is it expressly noted elsewhere in the records of the negotiation put in evidence. This is not surprising. As Dickson J. mentioned with reference to the west coast in Jack, ... in colonial times the perception of the fishery resource was one of "limitless proportions." 26

This passage says two things. First, it says that there was no mention in either the treaties or in the records of the question of a right to fish being raised. Second, it gives a reason why the question would not be raised: because the fishery was perceived as

the right to sell fish locally? Would the two Indian women referred to at 519 , para. 2 of the majority judgment, who apparently sold their fish to a missionary about 1758 "without arrest or other incident," have been required, at least while truckhouses were provided, to journey to a truckhouse to sell their fish on pain of being in breach of the treaties? Was it intended that the missionary who bought the fish, if he bought fish from an Indian woman while truckhouses were provided, would be subject to "arrest or other incident" under the "enabling" Nova Scotia statute which prohibited trade with the Indians?

$26 \quad$ lbid. at 539 , para. 42. 
limitless, it would not have occurred to the parties that there was any need for a treaty term conferring a right to fish. There is no basis in the facts recited in the majority judgment, nor is there any basis in any inferences which can be drawn from those facts, for deciding that either the British representatives or the Mi'kmaq representatives intended that the 1760-1761 treaties should include a term conferring a fishing right, or that either side even gave any consideration to the inclusion of such a term. In fact, the evidence of the Maliseet/Passamaquoddy meeting referred to in the majority judgment is inconsistent with a common intention to include a fishing right in the treaties and is entirely consistent with a common lack of intention to include such a term. It follows from the evidence cited by the majority judgment that it was not the common intention of the parties, or even the unilateral intention of any of them, to put a fishing-right term in the 1760-1761 treaties. If such a term is in the treaties, it has arisen without the volition of the parties.

\section{ShOUld A TeRm Giving Fishing Rights Be IMPLIEd?}

The majority judgment says:

The law has long recognized that parties make assumptions when they enter into agreements about certain things that give their arrangements efficacy. Courts will imply a contractual term on the basis of presumed intentions of the parties where it is necessary to assure the efficacy of the contract.... ${ }^{27}$

This is a correct statement of the general law. The implication of a term to assure the efficacy of a contract is a limited exception to the general proposition that terms are not placed into contracts or treaties without the volition of the parties. As I have already noted, for example, a court would, on ordinary contract principles, imply in the Mi'kmaq treaties some obligation on the British to maintain truckhouses, or, at the very least, would imply that the term requiring the Mi'kmaq to trade only at truckhouses would have effect only if there were truckhouses at which they could trade. The implication could be made without the evidence that the Passamaquoddy/Maliseet asked for truckhouses and that the Governor agreed to provide truckhouses. That is because a restriction on the Mi'kmaq to trading with truckhouses necessarily contemplated the existence of truckhouses for its efficacy.

The majority judgment imputed to the traditional officious bystander the question: "This talk about truckhouses is all very well, but if the Mi'kmaq are to make these promises, will they have the right to hunt and fish to catch something to trade at the truckhouses?"28 If the Governor and the Mi'kmaq would necessarily have answered with an unqualified affirmative, the Court should imply such a term on the basis of ordinary contract law. But the majority judgment did not impute an unqualified answer to the parties. What the judgment said was "the answer would have to be, having regard 
to the honour of the Crown, 'of course."'29 That is not an unqualified affirmative. It does not answer the question whether or not a term granting hunting and fishing rights was necessary to give efficacy to the treaty or to the truckhouse clause. It may even imply a negative answer to the latter question, as it seems that the answer that the parties would have given to the officious bystander would have been "of course" only if regard is had to the "honour of the Crown," which is a factor extraneous to efficacy.

Some of the language used in the majority judgment suggests that the true analysis is that (a) the treaties conferred on the Mi'kmaq a general right to trade in fish, among other things, and that (b) a general right to trade necessarily includes a right of access to fish in order to acquire the commodities to trade. But Binnie J. negatives any such proposition:

While I do not believe that in ordinary commercial situations a right to trade implies any right of access to things to trade, I think the honour of the Crown requires nothing less in attempting to make sense of the result of these 1760 negotiations. $^{30}$

That is to say, the mere fact that "the interpretation adopted by the courts below left the Mi'kmaq with an empty shell of a promise"31 was not enough to require the implication of a fishing-rights term in the treaty under ordinary contract law, in the absence of any intention of either party to put it there. It is only the requirement of upholding the "honour of the Crown" which caused the majority to read the term into the treaties.

So, the discussion to this point has, in my submission, established, on the basis of the evidence cited in the majority judgment and the majority's analysis, that:

(a) the Governor and the Mi'kmaq did not agree (nor did either of them intend) that a term giving the Mi'kmaq a fishing right was to be included in the treaties; and

(b) a term giving the Mi'kmaq a hunting and fishing right was not necessary to assure the efficacy of the treaties and would not be implied by the Supreme Court of Canada under ordinary contract law.

That is, there is no interpretation of what the parties said and did which would include in the treaties a term conferring a hunting and fishing right.

Ibid. This is, of course, the answer which both the Governor and the representatives of the Mi'kmaq would, in the majority's view, have necessarily given to the officious bystander's question. 
D. Did the "Honour of the Crown" Require that the Treaties Contain a Term Granting the Mi'kmaq a fishing Right, Perpetual or OTHERWISE?

\section{THE RATIO DECIDENDI}

The majority's ratio decidendi for its finding that the treaty included a term conferring on the Mi'kmaq a treaty right to fish ${ }^{32}$ is:

(a) the "honour of the Crown" required that such a term be included in the treaties, and

(b) the term is therefore implied in the treaties without the volition of the parties.

This appears from two passages in their judgment. The first is the threshold statement:

I would allow this appeal because nothing less would uphold the honour and integrity of the Crown in its dealings with the Mi'kmaq people to secure their peace and friendship, as best the content of those treaty promises can now be ascertained. ${ }^{33}$

That passage might be interpreted to mean that the honour and integrity of the Crown operates only in relation to otherwise ascertainable treaty promises. However, the second passage is divorced from the need to find a promise by the Crown:

While I do not believe that in ordinary commercial situations a right to trade implies any right of access to things to trade, I think the honour of the Crown requires nothing less in attempting to make sense of the result of these 1760 negotiations. ${ }^{34}$

In the majority's conception, therefore, in treaties with aboriginal groups, the "honour of the Crown" operates apart from the volition of the Crown and of the other parties to the treaty.

\section{Legal Nature of "The Honour of the Crown"}

It is not clear why the Supreme Court of Canada has developed a notion of the "honour of the Crown," which operates as a source of Crown obligation independently of the volition of both the Crown and aboriginal groups who are parties to treaties. In

32 It seems that the Mi'kmaq must have both the general right and the treaty right, as the general law would confer the general right on all citizens and there is no reason why the Mi'kmaq should not enjoy the general rights of all citizens. That would give the Mi'kmaq the right to fish without being limited to fishing for a subsistence livelihood, but the excess over fishing for a subsistence livelihood would be subject to the arbitrary provisions of the Fisheries Act and regulations, while the right to fish for a subsistence livelihood would be subject to regulation which meets the Badger test. Of course, how to determine whether or not each individual's hunting and fishing is more than enough to provide a subsistence livelihood would be a daunting administrative problem.

33 Marshall, supra note 1 at 520, para. 4.

34 Ibid. at 541 , para. 44 . 
earlier Supreme Court of Canada decisions, the notion was a guide to the interpretation of treaties between the Crown and aboriginal groups, and it was referred to as the basis of a fiduciary obligation in the carrying out of treaty promises. The majority decision in Marshall carries it further: either "the honour of the Crown" imposed a positive obligation on the Crown to include in the 1760-1761 treaties a term which was not contemplated by the parties to the treaties and which would not be in the treaties but for the requirements of the "honour of the Crown," or the policy of the law is to read into treaties terms which the courts consider to be required by the "honour of the Crown."

The notion of the "honour of the Crown" is not fact-based in the sense that it can be shown that the Crown has customarily acted honourably, or, at least, the majority judgment does not point to any factual basis for the existence of the "honour of the Crown." Centuries of English history deny that it has been a governing principle. Magna Carta was imposed on the Crown, in part, because the Crown had not acted honourably. The 1689 Bill of Rights ${ }^{35}$ and the 1701 Act of Settlement, ${ }^{36}$ which in 1760 were not yet 75 years into the past, were imposed upon the Crown because the Crown had not acted honourably. The Canadian Charter of Rights and Freedoms ${ }^{37}$ was imposed on the Crown and legislatures because the "honour of the Crown" is not a sufficient safeguard to ensure that the Crown, and the legislatures of which the Crown is a component, will act honourably with respect to all citizens. Ironically, the majority's interpretation of the 1760-1761 treaties leaves the "honour of the Crown" in tatters in this case: by 1762 or 1764 , the Crown had repudiated its solemn promises to maintain truckhouses for the Passamaquoddy, the Maliseet, and the Mi'kmaq. ${ }^{38}$ Rather than being fact-based, the notion of the "honour of the Crown" has all the earmarks of a legal fiction. ${ }^{39}$

The notion of the "honour of the Crown" is applied only to dealings between the Crown and aboriginal groups. There is no principle elsewhere in the law that the

1 Will. \& Mar., Sess. 2, c. 2.

$12 \& 13$ Will. III, c. 2.

Part I of the Constitution Act, 1982, being Schedule B to the Canada Act, 1982 (U.K.) 1982, c. 11.

The majority treated the disallowance of the "enabling legislation," An Act to prevent any Private Trade or Commerce with Indians, SNS 1760, c.11, as effectively terminating the truckhouse system, the King by so doing having made the truckhouses "temporary" when they were not temporary under the treaties. As the Act did not "enable" the maintenance of truckhouses, the majority presumably considered that it was necessary for the viability of the truckhouse system to prevent the Mi'kmaq from trading elsewhere. It is perhaps worthy of note that the disallowance was effected by George III, who succeeded to the throne in 1760, so that the disallowance may be regarded as an early experiment by that monarch in techniques of dealing with colonies.

It will be remembered that the old maxim "the King can do no wrong" did not mean that a punctilious sense of honour made the King incapable of straying from the paths of righteousness. Rather, it meant that the King could not be held legally responsible for the wrongs that he committed, that is, that the law would not recognize an act as legally wrong if it was the King who performed it. As the English legal humorist A.P. Herbert pithily stated the true situation through the mouth of his Lord Chancellor: "For in origin, 1 suspect, these words were not so much a testimony to royal infallibity as a convenient excuse for royal misfeasance." Uncommon Law, New ed. (London: Redwood Press Limited, 1969) at 293. 
"honour of the Crown" affects the interpretation of treaties or contracts which the Crown enters into with parties other than aboriginal groups, or that requires the inclusion in such treaties or contracts of terms not discussed by the parties and not implied on ordinary contract principles. ${ }^{40}$ So it seems that the law can do without the notion quite nicely, except in this one relationship.

The actual effect of what the Supreme Court of Canada has done with the notion of the "honour of the Crown" is to hold that the Crown stood in a confidential relationship with aboriginal groups and that the confidentiality of the relationship imposed on the Crown a duty to adhere to standards of conduct higher than those which are imposed by ordinary commercial morality. It would, in my submission, be better to put it that way. A relational analysis can yield the desired result (the imposition of a higher standard of conduct on the Crown) without giving as the source of the higher duty an undefinable abstract notion stated in almost mystical terms. It would be better to state the proposition directly rather than to explain it by bringing in a concept of "the honour of the Crown."

\section{CONTENT OF THE "HONOUR OF THE CROWN"}

It is not clear what the content of the "honour of the Crown" and the duties flowing from it are. This vagueness gives rise to difficulties.

The notion has been used as the basis of a rule that ambiguities are to be resolved against the Crown. In that context, it is contained and is not harmful. It has also been used as the basis of a rule that the Crown is in the position of a fiduciary in carrying out treaties with aboriginal groups. In that context also, it is contained and is not harmful. In both contexts, it would still be better to base the rules directly on the nature of the relationships between the Crown and aboriginal groups and on the rights and duties to which those relationships give rise.

But to say that the notion may require the inclusion of a term in a treaty or contract independent of the volition of the Crown and the other parties to the treaty or contract is to take a vague and imprecise term and to make it even more vague and imprecise. It is not apparent what "the honour of the Crown" means and what its ramifications are. If a fishing-rights term was added to the agreed treaty because the "honour of the Crown" required it, does that mean that a twentieth (or twenty-first) century Canadian court should review all the circumstances of treaties with aboriginal groups and decide what treaties the Crown ought, in all honour, to have entered into one or more centuries earlier? Perhaps an honourable Crown would not have accepted the submission of the Mi'kmaq to King George II's sovereignty and law at all, or perhaps an honourable

The majority judgment does refer to two cases from the time of James II (though it attributes them to the 18th century) in which the "honour of the Crown" was invoked to ensure that Crown grants were effective to accomplish their intended purposes. See Marshall, supra note 1 at 543, para. 50. It does not seem, however, that the majority's research detected any surfacing of the "honour of the Crown" between those cases and its first mention in a dissenting Supreme Court judgment in 1895. 
Crown would have given more for that submission than the general rights of British subjects, freedom from war, and an ephemeral promise of truckhouses. If one term was included in the 1760-1761 treaties though not agreed upon, and if there are other terms which the Crown ought in honour to have offered, the latter are still sleeping in the 1760-1761 treaties and all other treaties with aboriginal groups awaiting revival by some prince's kiss.

\section{ACtivation OF THE "HONOUR OF THE CROWN"}

But let us assume that the foregoing discussion is misguided and that the "honour of the Crown" imposes higher duties than commercial morality would suggest. Let us assume further that the higher duties include putting into treaties provisions not bargained for, asked for, or even mentioned by, aboriginal groups. On those assumptions, was there any reason to impose a duty to include a fishing-rights term in the 1760-1761 treaties? There could, in my submission, be no such reason, even on the stated assumptions, unless the inclusion of the term was necessary to confer a significant advantage on the Mi'kmaq which they should, in honour, have received. The significant advantage could only be in relation to the content of the treaty fishing right or in the legal protection afforded the treaty fishing right.

The Mi'kmaq enjoyed the general fishing right held by all British subjects. The treaty fishing right did not have any greater content. This is clear from the discussion of the majority judgment. ${ }^{4 !}$ Specifically, Binnie J. refers to "[t]he fact the content of Mi'kmaq rights under the treaty to hunt and fish was no greater than those enjoyed by other inhabitants." ${ }^{42}$ There was therefore nothing that the Mi'kmaq could do if the treaty fishing-right was conferred that they could not do if the treaty fishing-right was not conferred. Indeed, the content of the treaty fishing-right found by the majority was less than the content of the general fishing-right, because the treaty right was limited to fishing for a subsistence livelihood while the general fishing-right enjoyed by all British subjects had no such limitation. To say that the "honour of the Crown" required the Crown to confer on the Mi'kmaq a right which the Mi'kmaq already had would not make sense.

As to protection, the majority judgment at para. 48 recognizes that:

Until enactment of the Constitution Act, 1982, the treaty rights of aboriginal peoples could be overridden by competent legislation as easily as could the rights and liberties of other inhabitants. The hedge offered no special protection.... ${ }^{43}$

Ibid. at 541, paras. 45-46.

Ibid. at 542-43, para. 48 [emphasis in original].

lbid. The "hedge" was the "great Hedge" promised by Lt.-Governor Belcher in 1761: "The Laws will be like a great Hedge about your Rights and properties, if any break this Hedge to hurt and injure you, the heavy weight of the Laws will fall upon them and punish their Disobedience." (Ibid. at para 47). 
That is to say, the inclusion of a fishing-right term in the 1760-1761 treaties would not have conferred any protection on the treaty fishing rights that was not enjoyed by the general fishing rights of all British subjects. The "honour of the Crown" did not, in my submission, require the Crown, however honourable it may have been, to include in the treaties for protection purposes a fishing-right term which would not receive any higher legal protection than the Mi'kmaq would have had if the term was not included; indeed, it would not have been honourable to persuade the Mi'kmaq that a treaty term was a hedge which would protect them when it could not in law do so.

The majority judgment then says:

The fact that the content of the right was no greater does not, unless those rights were extinguished prior to April 17, 1982, detract from the higher protection they presently offer to the Mi'kmaq people. $^{44}$

So what it comes down to is this: since 1982, treaty rights offer more protection than general rights, so that the "honour of the Crown" as it stands in 1999 requires the inclusion of a fishing right in a treaty entered into more than 200 years earlier at a time when the treaty fishing right did not offer more protection than did the general fishing right enjoyed by all British subjects.

But to impose on the "honour of the Crown" an obligation to include a term in the 1760-1761 treaties because that term became constitutionally protected more than 200 years later is, in my submission, to impose a retroactive burden which is not reasonable. If the "honour of the Crown" requires a contemporary court to find that the 1760-1761 treaties included a term which the parties did not agree to, the requirement ought to be based only on the totality of facts that the actors could have known or foreseen in 1760-1761.

In my submission, a court which considered the 1760-1761 treaties at any time between 1760 and 1981 would have found no grounds to hold that the "honour of the Crown," however punctiliously it might be regarded, required that the treaties contain a fishing-right term; there was no benefit which the treaty fishing-right term would confer on the Mi'kmaq and no evil which it would protect them against. It did not in fact protect them against the Fisheries $A c t^{45}$ and regulations. It was not until 1982 that the benefit of a protected treaty right appeared, and it would not be appropriate to go back and insert a new term in the treaties at or after that point.

\section{Summary AND CONClusion}

The majority directed themselves correctly in their judgment:

"Generous" rules of interpretation should not be confused with a vague sense of after-the-fact largesse. The special rules are dictated by the special difficulties of ascertaining what in fact was 
agreed to. The Indian parties did not, for all practical purposes, have the opportunity to create their own written record of the negotiations. Certain assumptions are therefore made about the Crown's approach to treaty making (honourable) which the Court acts upon in its approach to treaty interpretation (flexible) as to the existence of a treaty (Sioui, supra, at p. 1049), the completeness of any written record (the use, e.g., of context and implied terms to make honourable sense of the treaty arrangement: Simon v. The Queen, [1985] 2 S.C.R. 387, ... and R. v. Sundown, [1999] I S.C.R. 393 ...), and the interpretation of treaty terms once found to exist (Badger). The bottom line is the Court's obligation to "choose from among the various possible interpretations of the common intention [at the time the treaty was made] the one which best reconciles" the Mi "kmaq interests and those of the British Crown (emphasis added) (Sioui, per Lamer J., at p. 1069). ${ }^{46}$

The "bottom line" imagery must mean that the ultimate distillation of the Court's obligation is that it is to interpret the common intention of the parties. If there are two interpretations of common intention, it is no doubt proper to take into account the fact, if it is a fact, that one interpretation better reconciles the interests of the parties to the treaty. But if the majority's words are intended to mean that the Court should read into a treaty a term which was not agreed to by the parties but which would better reconcile the interests of the parties, viewed objectively, than would the treaty which the parties actually entered into which did not include the non-agreed term then, in my submission, the Court has fallen into serious error.

The following is, in my submission, a summary of the fundamental points decided by the majority judgment with respect to the interpretation of the treaties which the Governor and the Mi'kmaq entered into:

1. The judgment held, correctly, that "the bottom line," which, as I have noted, presumably means the ultimate distillation of the Court's obligation in the interpretation of a treaty, is to interpret common intention.

2. The judgment held, correctly, that there was no reference in the historical record or in the formal documents to any intention, common or otherwise, that the 1760-1761 treaties were to contain, or did contain, a term conferring fishing rights on the Mi'kmaq.

3. The judgment held, correctly, that there was no common assumption, based on what was agreed to, that a fishing-right term was necessary to the efficacy of the treaty, so that no such term could be implied on ordinary legal principles.

Marshall, supra note 1 at 526, para. 14 [emphasis added]. The majority judgment also stated the ultimate question correctly at ibid. at 523, para. 7: "The question is whether the underlying negotiations produced a broader agreement between the British and the Mi'kmaq, memorialized only in part by the Treaty of Peace and Friendship, that would protect the appellant's activities that are the subject of the prosecution." That is to say, in order to find that Mr. Mashall's activities were protected, it is necessary to find "a broader agreement" between the parties to the 1760-1761 treaties which contained provisions protecting his right to fish. But the decision was that the honour of the Crown - not the narrower or broader agreement of the parties - put the protective term into the treaties. 
These findings make it clear that there is no interpretation of what the parties said, did, or agreed to, which would include in the treaties a term conferring a hunting and fishing right.

The judgment then enunciated a legal proposition which is entirely irrelevant to the "bottom line" of common intention, that is, that the "honour of the Crown" may require a term to be included in a treaty whether or not it reflects the common intention of the parties to the treaty. The majority judgment went on to hold that in this case, the "honour of the Crown" required that the treaty contain a term conferring on the Mi'kmaq a right to fish to the extent necessary to provide necessaries.

In my submission, by holding that the "honour of the Crown" requires that a term be inserted into the 1760-1761 Mi'kmaq treaties which the parties did not put there, the majority departed from its own self-direction by confusing "a vague sense of after-thefact largesse" with "generous rules of interpretation." That is, the constitutionalization of treaty rights in 1982 has given rise to a vague sense that a fishing right should be added to the 1760-1761 treaties although it "is not mentioned in the March 10, 1760 document, nor is it expressly noted elsewhere in the records of the negotiation put in evidence." interpreted treaties that the Crown ought to have entered into rather than the 1760-1761 treaties that the Crown did enter into, and has been led to the conclusion that the Crown ought unilaterally to have included a fishing-right term in the treaties by the fact that aboriginal treaty rights were given constitutional protection in 1982.

Of course, despite anything said in this comment, the majority's decision in Marshall has conclusively established that the 1760-1761 Mi'kmaq treaties include a term conferring a fishing-right on the Mi'kmaq, however and whenever the term arrived in the treaties. 